\title{
製鋼スラグ製品を用いた藻場・魚礁マウンド への生物着生

\author{
ADHESION OF PLANTS AND ANIMALS ON STEEL MAKING SLAG \\ MOUND IN COASTAL SEA AREA
}

\author{
宮田康人 1 ・本田秀樹 $2 \cdot$ 薮田和哉 3 ・林明夫 $4 \cdot$ 山本民次 5 \\ Yasuhito MIYATA, Hideki HONDA, Kazuya YABUTA, \\ Akio HAYASHI and Tamiji YAMAMOTO

\begin{abstract}
1工修 J F E スチール株式会社スチール研究所（†721-8510 広島県福山市鋼管町1）
2正会員 工修 J F E スチール株式会社スチール研究所（†210-0855 川崎市川崎区南渡田町1-1）

3 工博 J F E スチール株式会社スラグ事業推進部（テ100-0011 東京都千代田区内幸町2-2-3）

${ }^{4}$ J F E スチール株式会社スチール研究所（†260-0835 千葉市中央区川崎町1）

5 正会員 農博 広島大学大学院生物圈科学研究科（干739-8528 広島県東広島市鏡山1-4-4）
\end{abstract}

\begin{abstract}
An applicability of steel making slag as material for construction of submerged sea reef was examined in the Seto Inland Sea. Coverage of macroalgae on the artificial sea reef was nearly $100 \%$ at 4 months after the construction, which was clearly higher than those of surrounding natural area $(<10 \%)$. Observations at 11 months later the construction, both in quantity and species number of fish were significantly high at the experimental site compared to the surrounding area. Benthic animals were also rich in species number and quantity at the sea reef, in which some species can be appropriate as feed for fish. It was proven that the artificial sea reef made of steel making slag is promising equipment to provide habitat for fish not only hiding space but also feed for fish.
\end{abstract}

Key Words : $\quad$ steel-making slag, steel-making slag block, seaweed reef, the Seto Inland Sea

\section{1. 概要}

日本の内湾沿岸域では，臨海部の埋め立てや海砂 の採取，直立護岸化などにより，浅場・干潟の消失， 赤潮・青潮の発生などの問題が顕在化している。一 方で，海域の栄養塩が減少する貧栄養海域や，これ により水産資源の減少や磯焼けと呼ばれる現象が発 生するなどの事例も報告されている1).

これまでに, 鉄鋼生産に伴い副生する鉄鋼スラグ の 1 種である製鋼スラグやその加工製品について, 沿岸環境改善技術に関していくつかの研究がなされ ている。製鋼スラグは海水浄化機能 ${ }^{2), 3)}$ ，鉄成分な どの溶出によるプランクトンや珪藻などの増殖効果 4), 5)，腐植土と組み合わせて鉄イオン供給を増やす 技術5) などが報告されている。また，製鋼スラグを 主原料とした海洋向けブロックの事例も報告されて (る ${ }^{7), 8), 9)}$. 一方で，塊状製鋼スラグ (ブロックなど に加工されていないもの)を底生生物の付着基盤と した事例は少なく ${ }^{10)}$ ，製鋼スラグ製品を組み合わせ た人工マウンドの事例は見当たらない.

本報では，藻場・魚礁造成のため，水深が深い場 所を嵩上げするための材料（嵩上げ材）など海域環 境修復材として製鋼スラグの適用性を検討するため,
製鋼スラグ製品を組み合わせた人工マウンドを造成 し, 施工前状況および施工後の生物相の経過調査を 行った.

\section{2. 製鋼スラグマウンドの計画概要}

設計した製鋼スラグマウンドの模式図および計画 断面を図-1に示す。製鋼スラグマウンドは J F E ス チール株式会社西日本製鉄所製のスラグ製品を使用 し，天然石，天然砂などを使用しておらず，天然資 源採取などの新たな環境負荷を与えないことを特徵 とする. 粒径13〜80mmに粒度調整した塊状の製鋼ス ラグ，人工石，および鉄鋼スラグ炭酸固化体で構成 される.これらの外観を写真-1に，製鋼スラグの化 学組成例を表-1に示す。人工石は，骨材に製鋼スラ グ，結合材に高炉スラグ微粉末などを用いた鉄鋼ス ラグ水和固化体を岩石形状に成形したものである7) 製鋼スラグ炭酸固化体は，粒状の製鋼スラグを成型 して二酸化炭素を吹き込み，製鋼スラグと反応・固 化させて製造したブロックである ${ }^{8)}{ }^{9)}$. 水深 $7.5 \mathrm{~m}$ の 海底に粒径13〜85mmに粒度調整した塊状の製鋼スラ グ嵩上げ材として敷設し, その上に藻場・魚礁材と 
して人工石（人頭大～ $1 \mathrm{~m}$ 径）および製鋼スラグ炭酸

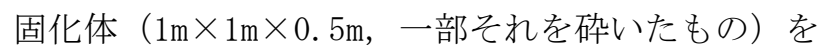
天端が約 $2.5 \mathrm{~m}$ とるように沈設し，すり鉢山状のマ ウンドを造成した。実海域試験場所は瀬戸内海沿岸 部とした。表-2に試験海域の主な水質計測結果を示 す,
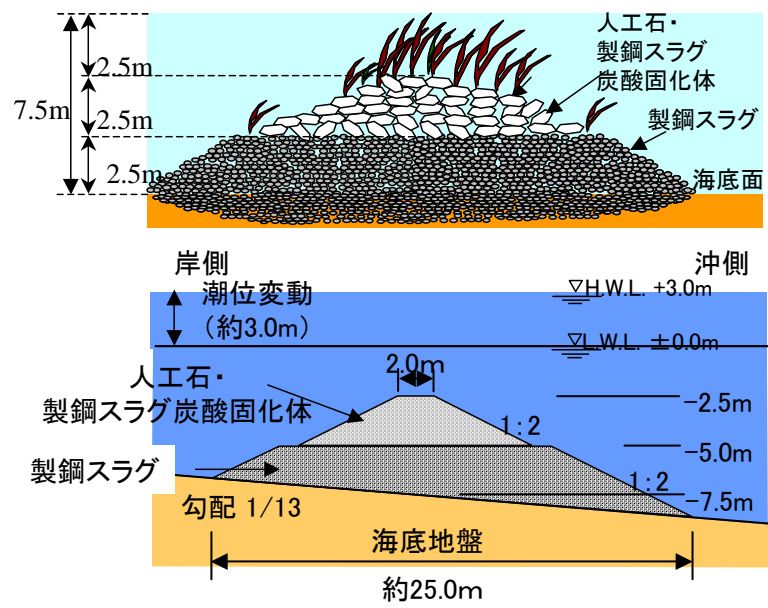

図-1 製鋼スラグマウンドイメージと計画断面

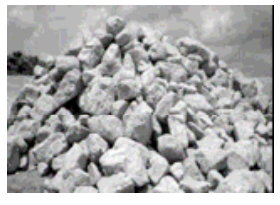

人工石 (人頭大以上)

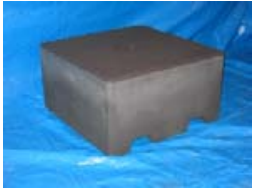

製鋼スラグ炭酸固化体 $\left(0.5 \mathrm{~m}^{3} /\right.$ 個)

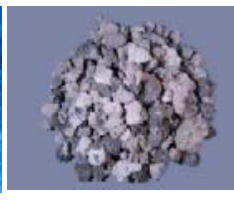

製鋼スラグ熄
写真-1 使用した製鋼スラグ製材料

表-1 製鋼スラグの化学組成例

\begin{tabular}{cccccccc}
\hline $\mathrm{SiO}_{2}$ & $\mathrm{CaO}$ & $\mathrm{Al}_{2} \mathrm{O}_{3}$ & $\mathrm{MgO}$ & $\mathrm{MnO}$ & $\mathrm{T}-\mathrm{Fe}$ & $\mathrm{TiO}_{2}$ & $\mathrm{P}$ \\
\hline 12.7 & 42.2 & 3.1 & 6.2 & 2.7 & 20.7 & 0.5 & 0.81 \\
\hline
\end{tabular}

表-2 試験海域の水質 (2009年8月に図-2のSt. 1で測定)

\begin{tabular}{c|c|c|c|c|c}
\hline & $\begin{array}{c}\text { 水深 } \\
\mathrm{m}\end{array}$ & $\begin{array}{c}\mathrm{pH} \\
-\end{array}$ & $\begin{array}{c}\text { 濁度 } \\
\mathrm{mg} / \mathrm{L}\end{array}$ & $\begin{array}{c}\mathrm{DO} \\
\mathrm{mg} / \mathrm{L}\end{array}$ & $\begin{array}{c}\text { 水温 } \\
{ }^{\circ} \mathrm{C}\end{array}$ \\
\hline 上層水 & 0.7 & 7.99 & 1.9 & 6.4 & 27.0 \\
\hline 中層水 & 4.1 & 7.99 & 1.4 & 6.3 & 26.7 \\
\cline { 2 - 6 } & 8.3 & 8.00 & 1.2 & 6.4 & 26.7 \\
\hline 下層水 & 10.8 & 8.01 & 2.3 & 6.5 & 26.6 \\
\hline
\end{tabular}

\section{3. 試験方法}

\section{（1）地盤調査および施工}

施工前の 2009 年 8 月に，ボーリング調査などの地 盤データ採取により，海底面の表層は砂泥質でその 下層が岩盤であること，円弧すべりなどの問題が生 じないことを確認するとともに沈下量を予測し，必 要なスラグ製品の必要量を算出した。施工は2009年 9月2日から15日にかけて行った。各スラグ製品の使
用量は，製鋼スラグ嵩上げ材が $1100 \mathrm{~m}^{3}$ ，人工石と製 鋼スラグ炭酸固化体が計 $130 \mathrm{~m}^{3}$ であった。

\section{(2) 生物調査}

\section{a）水中観察による海藻, 魚類調査}

施工前調査として2009年8月に水中観察により原 地盤の生物生息を調査した。施工後の生物観察は, 2009年9月（設置10日後），2009年10月（1力月後）, 2010年1月（4力月後），3月（6力月後），6月（9力 月後），8月（11ケ月後）および12月（15力月後） に図-2の人工石および製鋼スラグ炭酸固化体（人工 石・製鋼スラグ炭酸固化体区; St. 1) ，製鋼スラ グ区（St.2，St. 5），原地盤区（St. 3， St.4, St. 8)，および天然岩礁区（St.7）について海藻着 生や魚類の蝟集状況の観察を行った。さらに11力月 後（2010年8月）には蝟集した魚類の種類数と数量 を約 $5 \mathrm{~m} \times 10 \mathrm{~m} の$ 範囲で計測した。

b) 底生生物の定量調査

図-2に示す施工前（ $\triangle$ で示す原地盤区3箇所）お よび施工後（製鋼スラグ2箇所およびマウンドから $5 \mathrm{~m} ， 20 \mathrm{~m}$ 離れた位置の原地盤2箇所）の調査区にて採 取した。施工前は2009年8月，施工後は2010年6月， 8月および 12 月に実施した。原地盤区は鉄製方型枠

(縦 $25 \mathrm{~cm} \times$ 横 $25 \mathrm{~cm} \times$ 厚み $15 \mathrm{~cm})$ を差し込んで枠内の 底質を採取し $1 \mathrm{~mm}$ メシュの篩にかけて篩上に残っ たマクロベントスの種類, 個体数および湿重量を測 定した. 製鋼スラグ区についても方型枠をスラグ上 に置き, 枠内の表層部を採取して $1 \mathrm{~mm}$ 篩上に残る付 着生物を測定した。

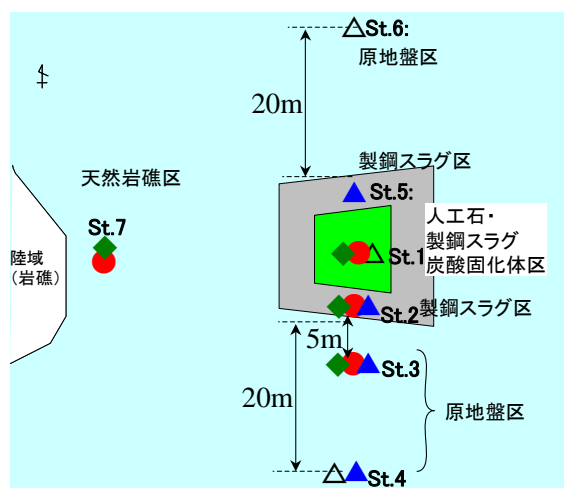

図-2 水中観察位置・底生生物サンプル採取位置 海藻類 : $\diamond$, 魚類観察 : 底生生物 : $\triangle$ (施工前), $\boldsymbol{\Delta}$ (施工後)

\section{4. 結果}

\section{(1) 藻類 · 海藻}

\section{a）人工石・製鋼スラグ炭酸固化体}

マウンド設置後の人工石・製鋼スラグ炭酸固化体 区の水中観察結果を写真-2 (a) に示す. 設置 1 ケ月 後には表層への藻類着生が観察された.4ケ月後に はナガミルの着生が観察され, 以降, 15 月後まで 観察された. 


\section{b）製鋼スラグ}

製鋼スラグ区の水中観察結果を写真-2 (b) に示す. 設置1ヶ月後には藻類の着生が認められた. 4ヶ月後 にナガミルが観察され，6ケ月後には定着・繁茂し， 以降11ヶ月後まで観察されたが，15力月後に衰退し ていた。

\section{c) マウンド周辺の天然岩礁および原地盤}

マウンド周辺の天然岩礁区および原地盤区の水中 観察結果を写真-2 (c) および写真-2 (d) に示す．砂泥 質の原地盤については施工前, 施工後全ての観察期 間を通じて海藻類は認められなかった。一方, 天然 岩礁については，人工石・製鋼スラグ炭酸固化体区 と同じ水深において, 紅藻類などが認められた。

\section{(a)人工石·鉄鋼スラグ炭酸固化体区}
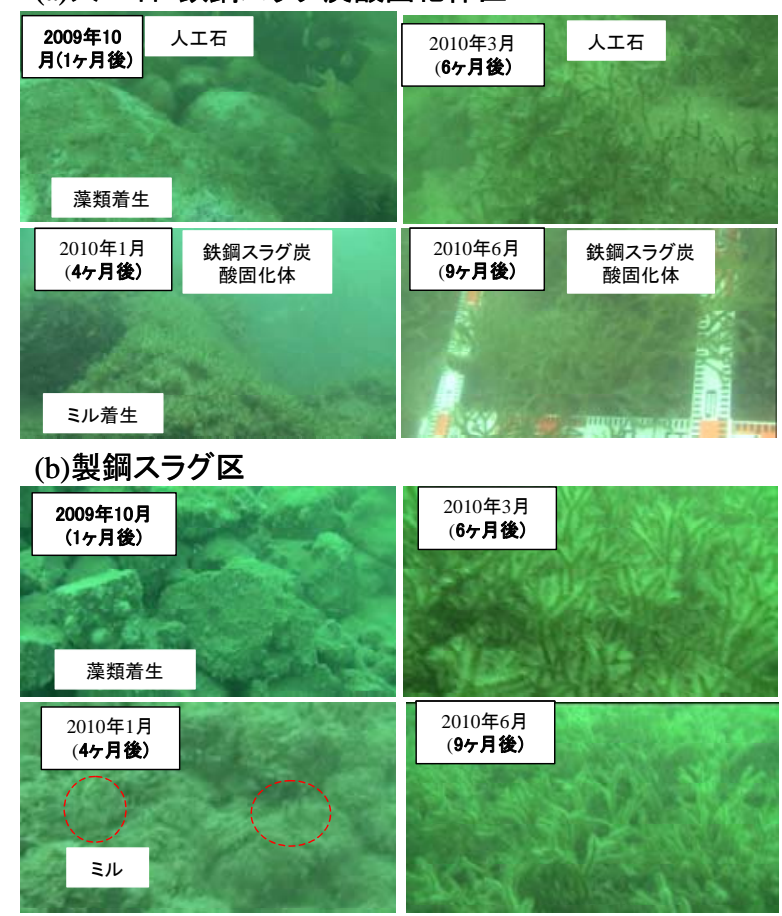

\section{(c)天然岩礁区}

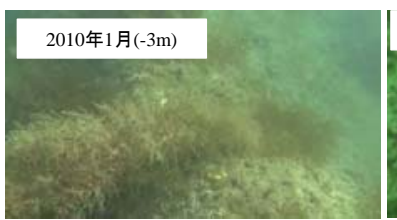

(d) 原地盤区

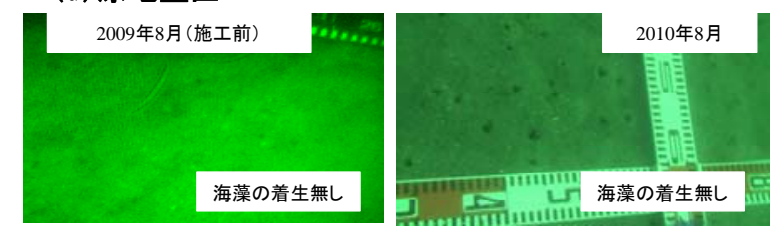

写真-2 海藻類の水中観察例

\section{d）海藻被度調査}

11力月後（2010年8月）の被度調査の結果を表-3 に示す. 人工石・製鋼スラグ炭酸固化体区および製 鋼スラグ区において，ミルが被度90〜100\%の被度で 着生した. 人工石と製鋼スラグ炭酸固化体の被度は
ほぼ同じであった。これに対し，原地盤は0\%，天然 石岩礁区（同一水深帯）は海藻の種類数は人工 石・製鋼スラグ炭酸固化体区を上回ったが被度は 10\%未満であった。

表-3 2010年8月における海藻類の被度調査

\begin{tabular}{|c|c|c|c|c|c|}
\hline \multicolumn{3}{|c|}{ 測定部位 } & 水深(m) & 海藻 & 被度(\%) \\
\hline \multirow{8}{*}{$\begin{array}{l}\text { スラグ } \\
\text { マウン } \\
\text { ド部 }\end{array}$} & 人工石·製 & 人工石1 & 3.6 & ナガミル & 100 \\
\hline & 鋼スラグ炭 & 资王石 & 3.2 & 五ガ & 95 \\
\hline & 酸固化体 & 製鋼スう崖酸固化体 1 & 3.4 & ナガミル & 100 \\
\hline & (St.1) & 製鋼スラグ炭酸固化体2 & 3.4 & ナガミル & 100 \\
\hline & & Et.2-1 & 8.6 & - & $=$ \\
\hline & 製鋼スラグ & Et. $2-2$ & 8.4 & - & $z$ \\
\hline & (St.2,St.5) & Et. $5-1$ & 6.0 & ナガミル & 100 \\
\hline & & Et.5-2 & 6.0 & ナガミル & 100 \\
\hline \multirow{5}{*}{ 比較 } & 岩礁部 & St.7-1 & 3.6 & 紅藻綱 & 5. \\
\hline & 石礁部 & St. $7-2$ & 3.5 & ナガミル & 5末満 \\
\hline & & St.3-1 & 110 & - & - \\
\hline & 原地盤 & St.8-1 & 7.5 & - & $=$ \\
\hline & & St. $8-2$ & 6.0 & - & $z$ \\
\hline
\end{tabular}

\section{（2）魚介類，メガロベントスなど}

\section{a）人工石・製鋼スラグ炭酸固化体}

人工石・製鋼スラグ炭酸固化体区の魚介類・メガ ロベントスの観察例を写真-3 (a) に示す。設置10日 後には魚影が観察され, 設置 1 ケ月後にはウマヅラ 八ギなどの稚魚の群れが観察された。4ケ月後には ナマコの着生が観察された. 6 月月後以降にはクロ メバル, クロダイ，およびマダイなどが観察された.

\section{(a)人工石·鉄鋼スラグ炭酸固化体区}

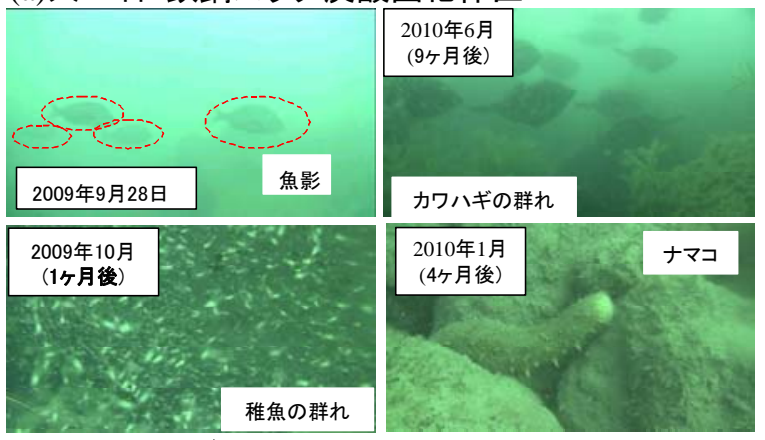

\section{(b)製鋼スラグ区}

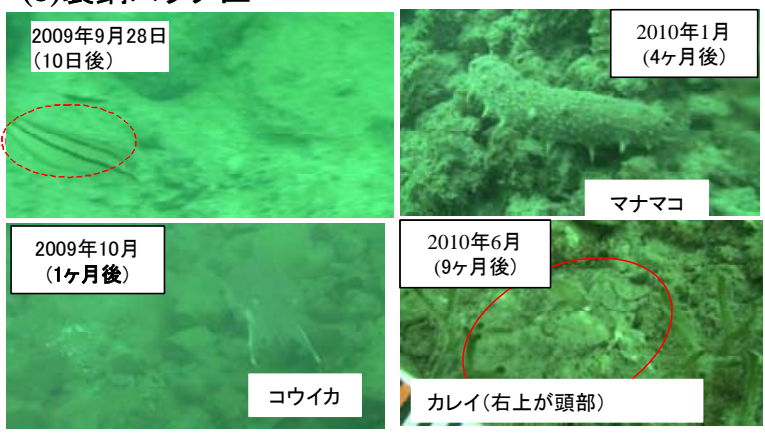

(c)天然岩礁区

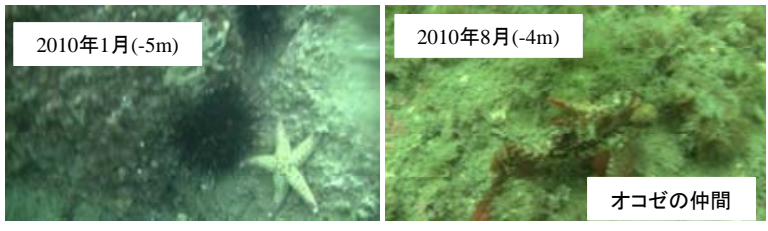

写真-3 魚介類・メガロベントスの観察例 


\section{b) 製鋼スラグ}

製鋼スラグ区の観察例を写真-3(a)に示す．設置 1 ケ月後以降, ウマヅラ八ギ, コウイカ, 八ゼ類, およびカレイなどの魚介類などが観察された。 4 ケ 月から8ケ月後まではマナマコが観察された.

\section{c) 天然岩礁および原地盤}

天然岩礁区の観察例を写真-3 (c) に示す. 水深が 浅い部位において, メバル，オコゼなどの魚類やマ ナマコ，ムラサキウニが認められた。一方，原地盤 区はヒトデ類の他は八ゼ類がわずかに確認された程 度と少なかった。

\section{d) 各区で観察された魚類の比較}

11 力後（2010年 8 月）に蝟集した魚類の種類数 と数量を計測した結果を表-4に示す. 人工石・製鋼 スラグ炭酸固化体区は 5 種, 製鋼スラグ区は 3 種, 天然岩礁区は 4 種, 原地盤区は 0 種であり, 人工 石・製鋼スラグ炭酸固化体区が最も多かったほか, 数量も他区に比較し多かった.

表-4 魚類調查（2010年8月）

\begin{tabular}{|c|c|c|c|c|}
\hline & \multicolumn{2}{|c|}{ スラグマウンド部 } & \multicolumn{2}{|c|}{ 比較 } \\
\hline & $\begin{array}{l}\text { 人工石·製鋼スラ } \\
\text { グ炭酸固化体区 } \\
\text { (水深-3 - }-4 \mathrm{~m})\end{array}$ & \begin{tabular}{|c|} 
製鋼スラグ区 \\
(水深 \\
$-6 \sim-8 \mathrm{~m})$ \\
\end{tabular} & $\begin{array}{c}\text { 天然岩礁区 } \\
\text { (水深 } \\
-3 \sim-4 \mathrm{~m})\end{array}$ & $\begin{array}{c}\text { 原地盤区 } \\
\text { (水深-8m) }\end{array}$ \\
\hline メバル & $\mathrm{CC}$ & & $r$ & \\
\hline クロダイ & $r$ & & & \\
\hline マダイ & $\mathrm{rr}$ & & $\mathrm{rr}$ & \\
\hline キュウセン & C & $\mathrm{r}$ & $r$ & \\
\hline カサゴ & & $r$ & & \\
\hline ウミタナゴ & & $r$ & & \\
\hline オコゼの仲間 & & & $\mathrm{rr}$ & \\
\hline 稚魚 (種不明) & $\mathrm{CC}$ & & & \\
\hline
\end{tabular}

\section{（3）製鋼スラグ区および原地盤区の底生生物}

製鋼スラグ区および原地盤区における底生生物同 定結果を図-3に示す.

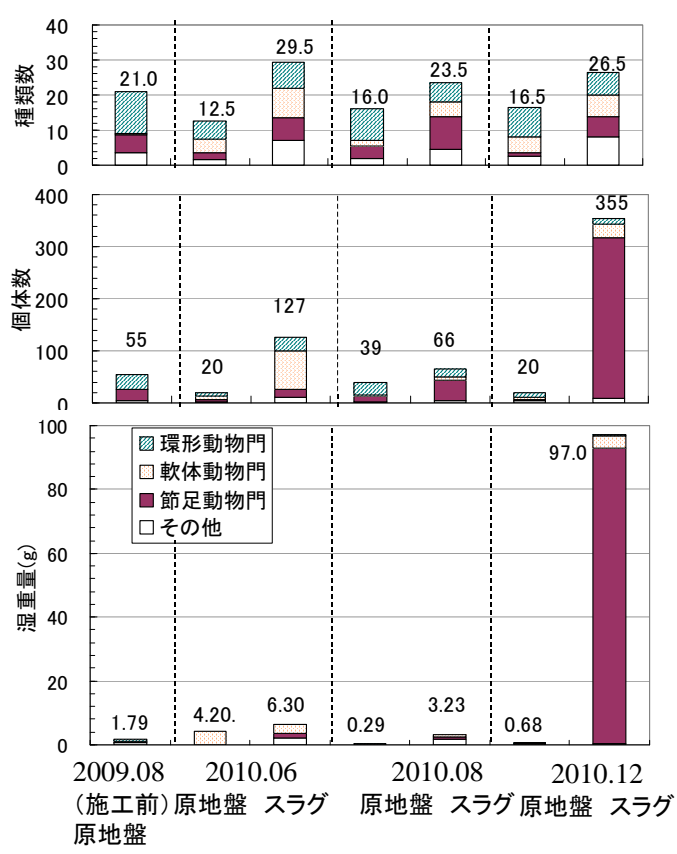

図-3 底生生物の種類数, 個体数, 湿重量の分析結果 (施工前原地盤はSt. 1, 4, 6, 施工後原地盤は St. 3, 4，製鋼スラグはSt. 2, 5平均)
製鋼スラグ区において，主な出現種は環形動物 (多毛綱) ウロコムシ，軟体動物門 (二枚貝綱) コ ケゴロモやユキミノ属, 節足動物門 (甲款類) サン カクフジツボやウエノドロクダムシなどであった. とくに12月においてサンカクフジツボは286個体, 湿重量 $92.4 \mathrm{~g}$ と優占していた.

原地盤区において主な出現種は環形動物（多毛 綱）ナガタンザクゴカイ，ケンサキスピオ，軟体動 物門 (二枚貝綱) シズクガイ, 棘皮動物門（蛇尾 綱）スナクモヒトデ，および原索動物門（頭索類） ナメクジウオなどなどであった.

製鋼スラグ区と原地盤区の種類数，個体数，およ び湿重量を比較すると，全期間において製鋼スラグ 区が施工前を含めた原地盤区を上回っていた。

\section{5. 考察}

\section{（1）海藻の着生}

人工石・製鋼スラグ炭酸固化体区への海藻着生は 多く，これまでの知見通りであった ${ }^{7), 10)}$. 一方, 製 鋼スラグ区は水深が深く, 太陽光が届きにくいため, 海藻の定着は難しいと予想していたが，定着した時 期は人工石・製鋼スラグ炭酸固化体区よりも遅れた ものの, 製鋼スラグ区にもナガミルが定着した。こ のことから本種は光量が少ない条件でも生息できる ものと考えられる.また, 人工石・製鋼スラグ炭酸 固化体区においても, 着生した海藻はナガミル 1 種 類に限られた。例えば，ホンダワラなどの幼体は主 に春季に着生することが知られており ${ }^{11)} ， 9$ 月に設 置した製鋼スラグマウンドには着生しなかったと推 察される.さらに, 比較的早期にミルが優占したた め他の海藻の着生が困難であった可能性もある. 海 藻の種類の増加については今後の経過調査を待つ必 要がある.

製鋼スラグ区において比較対照となる水深に天然 岩礁や転石が無いため同じ海域での比較ができない が, 筆者らは, 別の海域での調査にて, 同一水深・ 形状の製鋼スラグ, 花崗岩およびコンクリートの藻 類の量を測定したところ, 着生量が花崗岩よりもや や多く、コンクリートよりも顕著に多かった ${ }^{12)}$. 製 鋼スラグ塊は天然石やコンクリートに比べ，微細な 凹凸が多いこと, 鉄などの供給効果により付着珪藻 の着生が促されている可能性がある ${ }^{5)}$.

以上より, 塊状の製鋼スラグが藻類にとって天然 石同等以上の付着基盤となりうることが推察された.

\section{（2）基質による底生生物出現傾向 a) 出現種の傾向}

底生生物の主要構成群である環形動物門（多毛 類），軟体動物門，節足動物門（甲殼類）の3群は, 污濁が進むほど多毛類の比率が大きくなり，軟体動 物門および甲凯類の比率は小さくなる傾向があり, とくに甲殼類は比較的污濁に弱いとされる ${ }^{13)}$.また, 
底生生物を指標とした内湾度の表現 が試みられて いる ${ }^{14)}$ ，原地盤区においては，施工前，施工後とも に一部の調査点を除き, 出現した動物門の種類は環 形動物門（多毛類）の比率が高かったほか, 軟体動 物門（二枚貝綱）シズクガイや棘皮動物門（蛇尾 綱）カキクモヒトデなど污濁（富栄養化）指標種が 出現した. しかし節足動物門 (甲殼綱) も出現して いる点などから, 污濁の進行程度は強くないと考え られた。一方，製鋼スラグ区は，環形動物門（多毛 類），軟体動物門，節足動物門（甲殼類），および その他の動物門が比較的バランスよく出現していた また，底生生物を指標とした污濁指標種に関しては, 中・貧栄養海域の指標となる生物とされる節足動物 門（端脚類）ウエノドロクダムシ（ドロクダムシ科 に属する）が出現していた。

設置15力月後の原地盤区および製鋼スラグ区の底 質粒度を分析（JIS A 1204） したところ, 原地盤区 は礫分 (2mm以上) が約 $2.9 \%$ と少なく, 砂分. シル 卜分，および粘土分が残りを占め，地盤材料分類は

「粒分混じり砂」であった。一方の製鋼スラグは碩 分が98\%を占める「分級された砅」であり，粒子間 の隙間が大きかった。北森は, 三河湾内の底生生物 を調査し, 中央粒径が大きい底質ほど底生生物の種 類数が増加したことを報告している ${ }^{15)}$. 製鋼スラ グの粒子間の隙間が大きいことが，浅場区域外の底 泥に比べて生物数, 重量, 種類が多かった要因の一 つである可能性がある. また, 礫に付着または固着 して生息寸る底生生物が多く観察されたことから隙 間が大きいことにより底生生物が付着・固着しやす い環境となっていることが推察された。

以上より，製鋼スラグ区においては原地盤に比べ, 底生生物の種類や量が多いだけでなく, かつ污濁度 が少ない環境が形成されていることが示唆された.

\section{b）クラスター分析による評価}

底生生物の群集構造を解析するため, 調査点間の 類似度指数 $(\mathrm{C} \pi)$ に基づいたMountfordの平均連結 法によるクラスター分析 ${ }^{16)}$ を行い，その結果を図一 4に示した.

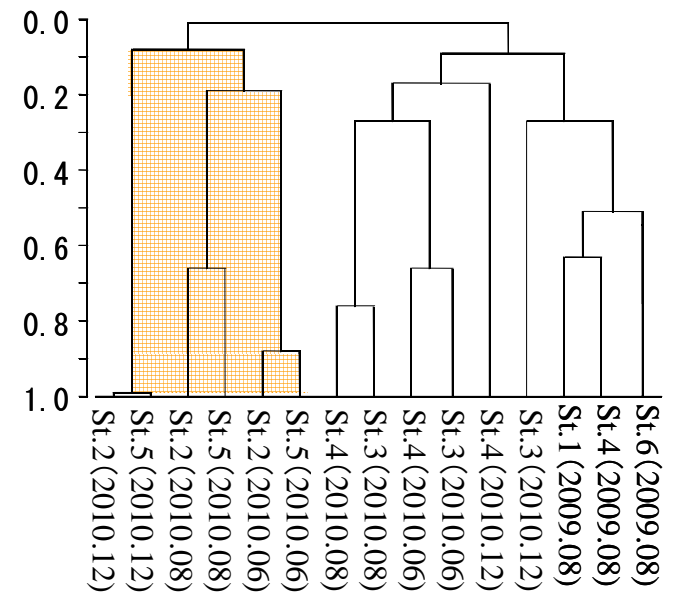

図-4 クラスター分析結果
その結果，製鋼スラグ区グループ (ハッチングで 示寸）と，原地盤グループの 2 グループに分けられ た. 従って, クラスター分析からもスラグ区と原地 盤区において，底生生物の生息状況の差があると判 断された.

\section{c) 魚類の餌生物としての底生生物}

出現した底生生物について魚類の餌生物としての 利用が予想される種の一覧を表-5に示した。底生生 物を餌生物として利用する魚類の例としては，メバ ル類やアイナメ類・ベラ類などの小型動物捕食者が 相当すると考えられ, 主に魚類・多毛類 - 外骨格の やわらかい甲款類などを捕食する ${ }^{17)}$ と報告されて いる. 他にも, 特にメバルの例ではエビ・カニ類, マダイの例では小型貝類なども捕食する ${ }^{18)}$.

製鋼スラグ区，原地盤区とも多毛類は安定して出 現していたが，製鋼スラグ区は小型甲殼類の種数が 顕著に多く, これらは魚類にとって有効な餌生物と なっている可能性が考えられた。一方，コケゴロモ

(貝類) やサンカクフジツボ (小型甲殼類) など付 着性生物も出現している. これらは成長すると強固 な款を持つことなどから，慨生物として利用できる のは一部の魚種に限られると考えられるが, 雑食性 のクロダイなどには利用される可能性がある.

表-5 魚類の餌生物と推察される種の一覧

\begin{tabular}{|c|c|c|c|c|c|c|}
\hline \multirow[b]{2}{*}{ 時期 } & \multirow[b]{2}{*}{ 区分 } & \multicolumn{4}{|c|}{\begin{tabular}{rrrrr|} 
主 な 魚 類 9 餌 生 物 \\
\end{tabular}} & \multirow[b]{2}{*}{ その他 } \\
\hline & & $\begin{array}{c}\text { 多毛類 } \\
\text { (環形動物門) }\end{array}$ & $\begin{array}{c}\text { 貝類 } \\
\text { (軟体動物門) }\end{array}$ & \begin{tabular}{|c|} 
小型甲殼類 \\
(節足動物門)
\end{tabular} & $\begin{array}{c}\text { 圠・加類 } \\
\text { (節足動物門) }\end{array}$ & \\
\hline \multirow[t]{2}{*}{$\begin{array}{l}\text { 施 } \\
\text { 前 } \\
\text { 前是 } \\
\text { 調查 }\end{array}$} & $\begin{array}{c}\text { 原地盤 } \\
\text { 区 }\end{array}$ & \begin{tabular}{|l|} 
Pista sp. \\
Euclymeninae \\
Amphinome sp. \\
他
\end{tabular} & 䖞师イ属 & $\begin{array}{l}\text { Euphilomedes- } \\
\text { sp. } \\
\text { ジポンスガ } \\
\text { ウシホタル }\end{array}$ & 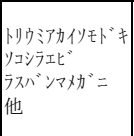 & \begin{tabular}{|l|} 
\\
キyュ \\
Cnemidocarpa \\
- \\
miyadii
\end{tabular} \\
\hline & 種数 & 23 & 1 & 3 & 8 & 6 \\
\hline \multirow{4}{*}{$\begin{array}{l}\text { 施 } \\
\text { 工 } \\
\text { 後 } \\
\text { 調 } \\
\text { 查 } \\
\widehat{6} \\
\text { 月 }\end{array}$} & $\begin{array}{c}\text { 原地盤 } \\
\text { 区 }\end{array}$ & $\begin{array}{l}\text { Capitella sp. } \\
\text { 付ゴムシ } \\
\text { 才沃チロリ } \\
\text { 他 }\end{array}$ & 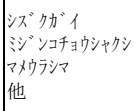 & \begin{tabular}{|l} 
フクタロガメ \\
Euphilomedes- \\
sp.
\end{tabular} & 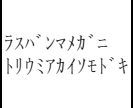 & $\begin{array}{l}\text { 仂リナマב科 } \\
\text { カ竹比デ” }\end{array}$ \\
\hline & 種数 & 9 & 6 & 2 & 2 & 2 \\
\hline & $\begin{array}{c}\text { 製鋼 } \\
\text { スラグ } \\
\text { 区 }\end{array}$ & \begin{tabular}{|l} 
Harmothoe sp. \\
Terebella sp. \\
Polydora sp. \\
他
\end{tabular} & $\begin{array}{l}\text { 斿ゴ吒 } \\
\text { キ外伤”イ } \\
\text { ユキミ属 } \\
\text { 他 }\end{array}$ & 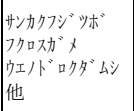 & 才才才シロピン & \begin{tabular}{|l} 
マクワボヤ \\
キヒトデ” \\
リ祊ス科 \\
他
\end{tabular} \\
\hline & 種数 & 13 & 11 & 10 & 1 & 9 \\
\hline \multirow{4}{*}{$\begin{array}{l}\text { 施 } \\
\text { 後 } \\
\text { 調 } \\
\text { 查 } \\
\text { 王 } \\
\text { 色 }\end{array}$} & $\begin{array}{c}\text { 原地盤 } \\
\text { 区 }\end{array}$ & 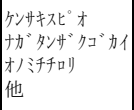 & 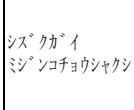 & $\begin{array}{l}\text { Euphilomedes- } \\
\text { sp. } \\
\text { アミ科 } \\
\text { スンサリョコヒビ }\end{array}$ & 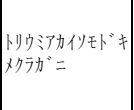 & 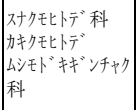 \\
\hline & 種数 & 13 & 2 & 3 & 2 & 3 \\
\hline & $\begin{array}{c}\text { 製鋼 } \\
\text { スラグ } \\
\text { 区 }\end{array}$ & $\begin{array}{l}\text { Harmothoe sp. } \\
\text { Nereis sp. } \\
\text { Lepidonotus } \\
\text { sp. } \\
\text { 他 }\end{array}$ & 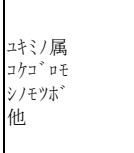 & 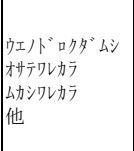 & 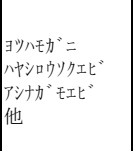 & $\begin{array}{l}\text { Discinisca } \\
\text { sp. } \\
\neq \text { 怰" } \\
\text { 吅”゙ } \\
\text { 他 }\end{array}$ \\
\hline & 種数 & 8 & 7 & 10 & 5 & 7 \\
\hline \multirow{4}{*}{$\begin{array}{l}\text { 施 } \\
\text { I } \\
\text { 後 } \\
\text { 調 } \\
\text { 查 } \\
\widehat{1} \\
2 \\
2 \\
\text { 量 }\end{array}$} & $\begin{array}{c}\text { 原地盤 } \\
\text { 区 }\end{array}$ & 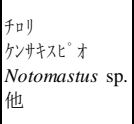 & 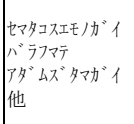 & 出現種なし & 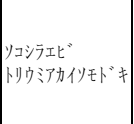 & 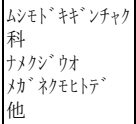 \\
\hline & 種数 & 14 & 9 & 0 & 2 & 4 \\
\hline & $\begin{array}{c}\text { 製鋼 } \\
\text { スラグ } \\
\text { 区 }\end{array}$ & $\begin{array}{l}\text { Nereis sp. } \\
\text { アケノサシパ } \\
\text { フタマタゴカイ } \\
\text { 他 }\end{array}$ & 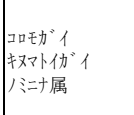 & 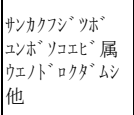 & 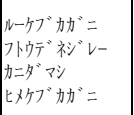 & $\begin{array}{l}\text { Discinisca sp. } \\
\text { 於トゲクモヒド } \\
\text { 多岐腸目 } \\
\text { 他 }\end{array}$ \\
\hline & 種数 & 11 & 10 & 5 & 3 & 13 \\
\hline
\end{tabular}




\section{（3）製鋼スラグマウンドの藻場・魚礁としての 有用性および使用時の留意点}

藻場が有する機能は，(1)（岩礁・転石への）海藻 着生場, (2)魚類の蝟集・稚仔の生育場の形成などが 挙げられる ${ }^{19)}$. 本研究において, 製鋼スラグマウン ドは，製鋼スラグ炭酸固化体・人工石区および製鋼 スラグにおいて, (1), (2)の機能が確認された.さら に製鋼スラグ区において, (1)の機能も確認されたほ か, 魚類の餌となりうる底生生物が着生しているこ とから間接的に(2)に関与していることが示唆された。 以上より，製鋼スラグマウンドが藻場・魚礁として の有用性が示唆された。今後も調査を継続し, 長期 的な動植物着生の継続性について検討する必要があ る.

なお、製鋼スラグマウンドの嵩上げ材として用い た製鋼スラグは，含有する石灰成分によりアルカリ 性を示すため ${ }^{20)}$, 周辺海水 $\mathrm{pH}$ への影響に留意する必 要がある。本試験では，微粒を除去して $\mathrm{pH}$ 上昇を抑 えた塊状製鋼スラグを用いた。施工（製鋼スラグ投

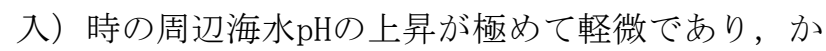
つ施工後速やかに施工前のpHに戻ることを確認した。

\section{6. まとめ}

海域環境修復材として製鋼スラグ製品を組み合わ せた製鋼スラグマウンドの適用性を検討するため, 実海域試験を計画し，2009年9月に施工した。これ までの調査において，以下の知見が得られた。

(1) 原地盤は砂泥質であり, 施工前・後とも海藻類 の着生は見られず, 観察された動物はヒトデ, 八ゼ 類などに限られた。

（2）設置4ヶ月後以降，魚礁・藻場として設置した人 工石・製鋼スラグ炭酸固化体区，嵩上げ材として設 置した製鋼スラグ区とも設置4ケ月後以降ミルが繁 茂し，11力月後（2010年8月）の被度調査において 100\%近い被度であった。これに対し，天然石岩礁区

(同一水深帯) は海藻の種類は天然岩礁が上回った が被度は10\%未満に留まった。

(3) 人工石・製鋼スラグ炭酸固化体区には設置 10 日 には魚影が観察され, 設置 1 力後以降ではクロダ イ, メバルなどの魚類の蝟集が観察された。製鋼ス ラグ区についてもハゼ類, カレイなどの魚類が観察 された.11カ月後（2010年8月）に蝟集した魚類の 種類数と数量を計測したところ，人工石・製鋼スラ グ炭酸固化体区が最も多かったほか, 量も他区に比 較して多かった。

(4) 製鋼スラグ区の底生生物は原地盤（砂泥質）区 よりも個体数, 種類数および湿重量とも多い傾向で あった。また礫間または碟に固着して生息する甲殼 類および二枚貝が多く着生した。これらはメバルな どの摂餌対象の種が多く，魚類の蝟集に寄与してい る可能性が伺われた。

以上のように，塊状製鋼スラグおよび製鋼スラグ
製品を組み合わせた製鋼スラグマウンドの藻場・魚 礁としての有用性が示唆された。 ただし設置後15 月までの調査であり，長期的な効果の継続について は今後の調査により明らかにする必要がある.

\section{参考文献}

1) 例えば, 海の自然再生ワーキンググループ:海の自然再生 ハンドブック その計画・技術・実践 第 1 巻総論編, 株式 会社ぎょうせい, 2003.

2) 伊藤一明, 西嶋涉, 正藤英司, 岡田光正: 鉄鋼スラグ散布 による沿岸海域でのリン除去の基礎的研究, 水環境学会 誌, 19, pp.501-507, 1996.

3) 伊藤一明, 西嶋渉, 正藤英司, 岡田光正:鉄鋼スラグ散布 による沿岸海域底泥からの硫化物抑制とアンモニア性窒素 の溶出の検討, 水環境学会誌, 20, pp.670-673, 1997.

4) Y.NAKAMURA, A.TANIGUCHI, S.OKADA, M.TOKUDA; ISIJ International, 38, pp.390-398, 1998.

5)鈴木雅巳, 山本民次: 製鋼スラグの添加が珪藻 Skeletonema costatum および渦鞭毛藻 Alexandrium tamarense の増殖に及ぼす影響(社会・環境), 鐵と鋼, 日 本鐵鋼協會々誌 91(10), pp.783-787, 2005.

6) 中川雅夫.越阪部裕也; 鉄鋼スラグ (鉄鋼副産物)の利用で 藻場を再生, 養殖, 47.No.5.pp.48-51, 2010.

7) 宇田川悦郎, 松永久宏: 鉄鋼スラグ水和固化体製人工石 材「フロンティアロック TM」, JFE 技報,19,pp. 18-22, 2008.

8) 高橋達人: 新材料としての製鋼スラグ炭酸固化体版下新材 料としての製鋼スラグ炭酸固化体, コンクリート工学, 38, pp.3-9,2000.

9) Tsuneo Isoo, Tatsuhito Takahashi and Minoru Fukuhara: Using Carbonated Steelmaking Slag Blocks to Help Reduce CO2, American Ceramic Society Bulletin, pp.73-75, 2001.

10) 宮田康人, 高橋達人, 薮田和哉, 戸澤宏一, 佐藤義夫: 製鋼スラグ潜堤材と製鋼スラグ炭酸固化体への生物着生, 日本海水学会誌, 60, No.3, pp.152-156, 2006.

11)能登谷正浩編: 藻場の海藻と造成技術, 株式会社成山堂 書店, pp.180-189, 2003.

12)宮田康人, 沼田哲始, 高橋達人, 豊田惠聖, 佐藤義夫: 鉄 鋼スラグを用いた沿岸環境改善, 第一回海環境と生物およ び沿岸環境修復技術に関するシンポジウム論文集, pp3742, 2002.

13)桑原連: 底生生物からみた生物指標. 横浜公害研究所, 公害研資料 No.88, pp 199-235, 1989.

14)菊池泰二:環境と生物指標-水界編-. 共立出版, 1975.

15) 北森良之介: 内湾の環境科学下 (西條八束編), 培風 館, pp.93-115, 1984.

16)木元新作: 動物群集研究法 I -多様性と種類組成-. 共立 出版, 1976.

17)西村三郎:海の生態学. 築地書館, 1972

18)日本水産資源保護協会:水生生物生態資料, 1981

19) 社団法人 海洋産業研究会: 多目的干潟・藻場・浅場の 造成に関する調查研究報告書 (昭和 63 年度後期自主研 究事業), pp.5, 1989.

20）鐵鋼スラグ協会: 環境資材鉄鋼スラグ, 鐵鋼スラグ協会, 1989. 